\title{
Erratum: Chemotherapy in metastatic NSCLC - new regimens (pemetrexed, nab-paclitaxel)
}

\section{Frontiers Production Office*}

Frontiers Production Office, Frontiers, Switzerland

${ }^{*}$ Correspondence: production.office@frontiersin.org

Approved by:

Oncology Editorial Office, Frontiers, Switzerland

Keywords: metastatic, non-small cell lung carcinoma, solvent-based paclitaxel, nab-paclitaxel, pemetrexed, histology, clinical trials

\section{An erratum on}

Chemotherapy in metastatic NSCLC new regimens (pemetrexed, nabpaclitaxel)

by Blais N, Hirsh V. Front Oncol (2014)

4:177. doi:10.3389/fonc.2014.00177

\section{REASON FOR ERRATUM}

In Table 2, the Median OS values (in months) in the column $\geq 70$ years were changed due to a typesetting error. This error does not change the scientific conclusions of the article in any way. The publisher apologizes for this error and the correct version of Table 2 appears below.

Received: 14 October 2014; accepted: 14 October 2014; published online: 30 October 2014.

Citation: Frontiers Production Office (2014) Erratum:

Chemotherapy in metastatic NSCLC - new regimens (pemetrexed, nab-paclitaxel). Front. Oncol. 4:300. doi: 10.3389/fonc. 2014.00300

This article was submitted to Thoracic Oncology, a section of the journal Frontiers in Oncology.

Copyright (c) 2014 Frontiers Production Office. This is an open-access article distributed under the terms of the Creative Commons Attribution License (CC BY). The use, distribution or reproduction in other forums is permitted, provided the original author(s) or licensor are credited and that the original publication in this journal is cited, in accordance with accepted academic practice. No use, distribution or reproduction is permitted which does not comply with these terms.

Table 2 | Select efficacy outcomes from the Phase III trial of nab-paclitaxel plus carboplatin in NSCLC

\begin{tabular}{|c|c|c|c|c|c|c|c|c|c|}
\hline Treatment & \multicolumn{3}{|c|}{ ITT (41) } & \multicolumn{2}{|c|}{$\geq 70$ years $(42)$} & \multicolumn{4}{|c|}{ Histology (43) } \\
\hline$n$ & 514 & & 524 & 74 & 82 & 229 & 221 & 292 & 310 \\
\hline ORR (\%) & 33 & & 25 & 34 & 24 & 41 & 24 & 26 & 25 \\
\hline Median PFS (months) & 6.3 & & 5.8 & 8.0 & 6.8 & 5.6 & 5.7 & 6.9 & 6.5 \\
\hline $\mathrm{HR}$ & & 0.902 & & & & & & & \\
\hline$p$-Value & & 0.214 & & & & & & & \\
\hline Median OS (months) & 12.1 & & 11.2 & 19.9 & 10.4 & 10.7 & 9.5 & 13.1 & 13.0 \\
\hline
\end{tabular}

HR, hazard ratio; IIT, intent-to-treat; nab-P/C, nab-paclitaxel+ carboplatin; NSCC, non-squamous cell carcinoma; NSCLC, non-Small cell lung cancer; ORR, overall response rate; OS, overall survival; PFS, progression-free survival; sb-P/C, solvent-based paclitaxel+ carboplatin; SCC, squamous cell carcinoma. 